\title{
Bioactive Compounds, Antioxidant properties, and Metal Content Studies of Guava Fruit by-products for Value Added Processing
}

\author{
Neela Emanuel*, Khushbu Sao, Aman Kaushik \\ National Institute of Food Technology Entrepreneurship \& Management (NIFTEM) \\ Kundli, Sonepat, Haryana, 131028, India
}

Fruit processing industries generate enormous amount of by-product materials which can be a valuable source of bioactive compounds. Guava fruit's by-products seed and pomace along with the peel were analyzed for antioxidant activity and bioactive compounds. In the present study the total phenolic content (TPC), evaluation of antioxidant activities using 2,2-diphenyl-1-picrylhydrazyl (DPPH) scavenging activity, Ferric Reducing Antioxidant Power (FRAP), Total Flavonoid content (TFC) were determined. The quantification of some of the bioactive phenolics was carried out using HPLC. The pomace along with the peel extract contained highest phenolic content $432 \mathrm{mg}$ gallic acid equivalent (GAE) per $g$ and possessed strong antioxidant activity in antioxidant assay. The mineral and toxic metals characterization was carried out using ICP-MS method after extraction process. The compound extracted from these by-products can be utilized as nutraceuticals in food, food ingredients, formulation of new improved healthier food products and pharmaceutical industries.

Keywords: polyphenols, antioxidant properties, carotenoids, flavonoids, nutrients, minerals, toxic metals, healthier product

\section{INTRODUCTION}

"Psidium guajava" (Guava) is an important tropical fruit with high nutritious value [1]. It is an excellent source of Vitamins C, A, B2 (Riboflavin) and minerals like calcium, phosphorus, potassium, sodium and iron [2]. It contains about 180-300 mg of vitamins per $100 \mathrm{~g}$ of pulp and high level of about 50-300 $\mathrm{mg}$ per $100 \mathrm{~g}$ of ascorbic acid [3]. Ripe Guava fruits contain 14.0 percent total soluble solids (TSS); 0.3 percent acidity; 7.0 percent fiber; 14.3 percent carbohydrate; 2.5 percent protein and 1.3 percent minerals [4-5]. It is also rich source of carotenoids and phenolic compounds which have been associated with diminished risk of diseases such as cardiovascular, certain carcinogenic disease, inflammation, hypertension, arthritis and neurodegenerative diseases [6-8].

Various processed products which were produced from Guava include beverages, syrup, juicewine, dehydrated and canned products. Guava processing industries generate large amount of the waste byproducts as peel, pomace and seed which contain valuable reusable bioactive compounds [8]. Recently, more emphasis is based on the extraction of the valuable products and their utilization as functional food, health supplement, neutraceutical product, food additives, food ingredients, medicinal and cosmetics [9-15]. The byproducts can be further processed to develop food products such as jams, jelly, velva frozen dessert and fruit leather [4,16].

Guava fruit contain enormous amount of essential nutrients and micronutrients such as phytochemical compounds, minerals, fibers and vitamins which are useful for the human health [7,11]. Recent study has shown that the fruit peel and seed contain considerable amount of phenolic compounds and ascorbic acid [17]. The role of the peel is to protect the inner portion of the fruit from pest and microorganisms [18]. Seed as the by-product of the fruit such as citrus, apricot kernel, and mango from food processing industry have been reported to contain phenolic compounds [19]. There is greater need to find different ways to utilize these byproducts containing bioactive compounds having antioxidant activity as food 
additives or supplements which eventually will increase the opportunity for commercial exploitations.

The extracted nutrients and polyphenols can be utilized for the further development of the functional food by addition as natural antioxidants during the processing of the food to improve health status. They can also be utilized as nutraceuticals in the medicinal form of pills, capsules or liquids. In both forms they provided demonstrated physiological benefits, improve health, and diminish disease risk through prevention [20]. Food enriched with natural antioxidants helps in the prevention of the development of diseases caused by oxidation stress. The exploitation of the byproducts of food processing industries as a source of functional compound and their application in food is promising field which require interdisciplinary research of food technologists, food chemists, nutritionists, and toxicologists. Nutraceuticals and functional foods provide a means to reduce the increasing burden on the health care system by continuous preventive mechanisms. The interest in nutraceuticals and functional foods continues to grow and is powered by progressive research efforts to identify properties and potential applications of nutraceutical substances, coupled with public interest and consumer demand [21-22].

Nutrients present in guava fruits both pink and white varieties are plentiful and diverse. However they contain both essential minerals and toxic metals over a wide range of concentrations. The transition metals like $\mathrm{Fe}, \mathrm{Cu}, \mathrm{Mn}$, and $\mathrm{Zn}$ occur naturally and they serve as plant nutrients depending upon their concentrations. On the other hand $\mathrm{Pb}, \mathrm{Cr}, \mathrm{Ni}, \mathrm{Hg}$, and many other heavy metals are indirectly distributed as a result of human activities which could be very toxic even at low concentrations [23].

Guava by-products are valuable raw materials as a source of polyphenols and nutrients. Thus, the present study was undertaken to assess total phenolic content, evaluate antioxidant activities, quantification of individual bioactive phenolic compounds, nutrients and toxic metal contaminants present in the peel, leftover pomace along with the seeds of guava waste. These products were taken for the study as they are generally generated from the fruits processing industries as waste byproducts and that can be utilized further for the formulation of various products and help in sustainable and stable growth of the food industries. The subsequent development of low cost technologically viable approach to convert guava by-products into nutraceuticals, food ingredients and the development of new healthier food products would help in reduction and disposal of byproducts and the production of value added food stuff.

\section{MATERIAL AND METHODS Chemical Reagents}

All the reagents used were analytical grade and obtained from Sigma Aldrich Inc., Thermo Fisher, Merck, Fluka and Milli-Q water. The glassware was thoroughly cleaned before use.

\section{Sample preparation}

Fresh guava both white and pink varieties of high quality with no visible scratch or spoilage were purchased in the spring season from Azadpur Mandi in Delhi. The by-products were obtained after extracting juice of guava containing guava peel, pulp and seed. The by-products of guava samples were lyophilized, homogenized, and stored at $-20^{\circ} \mathrm{C}$ in a sample bottle protected from light. Moisture content was determined for samples using standard method [24]. Total protein, ash content, crude fiber, and total fat content were determined according to the standard method of analysis [25].

\section{Extraction process}

The extraction of the phenolic content was carried out by the following procedure: $2.56 \mathrm{~g}$ of powdered, freeze dried samples were weighed on analytical microbalance and transferred to centrifuge tubes. Two step extractions were carried out and were combined for the subsequent analysis. In the first step the weighed sample was mixed with $20 \mathrm{~mL}$ ethanol:water $(50: 50, \mathrm{pH} 2)$ solution and homogenized using orbital shaker incubator (New Brunswick Scientific) at $300 \mathrm{rpm}$ for 60 minutes. The supernatant solution was separated and kept aside and the residue was used for the second step extraction. The 
remaining residue sample was treated with $20 \mathrm{~mL}$ of acetone:water mixture $(70: 30, \mathrm{v} / \mathrm{v})$ and extraction was carried out as mentioned in the first step. The supernatant was recovered and mixed with the first step solution and diluted to $100 \mathrm{~mL}$. The extracts obtained were evaluated for the presence of various phytochemicals by chemical tests using standard procedures [26-28].

\section{Physicochemical analysis}

Qualitative Phyto-chemical Analysis

The extracted sample solutions were analyzed qualitatively for the presence of bioactive compounds by using standard method [29].

\section{Determination of Total Phenolic Content (TPC)}

Total phenolic content in the sample solution was determined by Folin-Ciocalteau reagent [30]. Equal amount of extracted sample solution and diluted Folin-Ciocalteau reagent were mixed together and kept for few minutes followed by addition of $1 \mathrm{~mL}$ sodium carbonate solution $(7.5 \% \mathrm{w} / \mathrm{v})$ and incubated at room temperature for one and half hours in the dark. The absorbance of the resulting solution was measured at $760 \mathrm{~nm}$ using UV-Vis spectrophotometer. Gallic acid was used as a standard. The results were expressed as mean \pm standard deviations of $\mathrm{mg}$ of gallic acid equivalent $100 \mathrm{~g}^{-1}$ extract.

\section{Total Flavonoid Contents}

Total flavonoid contents in the sample solution were determined using the aluminum chloride colorimetric assay. The $1 \mathrm{~mL}$ sample extract, $2 \mathrm{~mL}$ distilled water and $0.3 \mathrm{~mL}$ of $5 \% \mathrm{NaNO}_{2}$ solution were combined in $10 \mathrm{~mL}$ volumetric flask and kept at room temperature for 5 minutes. In this solution, 3 $\mathrm{mL}$ of $10 \% \mathrm{AlCl}_{3}$ solution was added followed by $2 \mathrm{~mL}$ of $1 \mathrm{M} \mathrm{NaOH}$ solution and the total volume was made up to $10 \mathrm{~mL}$ with distilled water. The absorbance of the solution was measured at $510 \mathrm{~nm}$ using a spectrophotometer. The concentration of flavonoid compound was estimated by calibration curve using quercetin as flavonoid reference. The results were expressed as mean \pm standard deviations of $\mathrm{mg}$ of quercetin equivalent $100 \mathrm{~g}^{-1}$ extract.

\section{DPPH Free Radical Scavenging Capacity}

Antioxidant activities were measured in triplicate for the extracted sample solution using DPPH assay. DPPH assay absorb strongly at wavelength $517 \mathrm{~nm}$ which is the $\lambda_{\max }$. When the phenolic compounds in the extract react with the stable DPPH radical, it remove the free radical which lead to the color change from blue complex to light yellow. The color change depends on the intrinsic concentration of available antioxidant and its rate of reactivity towards DPPH. The degree of reduction in absorbance measurement is indicative of the radical scavenging power of the extract. The measurement of the DPPH radical scavenging activity was performed according to described methodology [31]. The samples were treated with the stable DPPH radical in the extracted solution. To the $1 \mathrm{~mL}$ sample solution in test tube was added $5 \mathrm{~mL}$ of absolute ethanol followed by $1.0 \mathrm{~mL}$ of $0.5 \mathrm{mM}$ DPPH radical solution. Absorbance was measured at $517 \mathrm{~nm}$ after $60 \mathrm{~min}$ of reaction using a UV-Vis spectrophotometer (Shimadzu 2600). The control solution was prepared by mixing ethanol ( $5 \mathrm{~mL}$ ) and DPPH radical solution $(0.5 \mathrm{~mL})$. The scavenging activity percentage (AA \%) was determined using the equation: DPPH free radical scavenging activity $(\%)=($ Absorbance Control-Absorbance Sample $/$ Absorbance Control) $\times 100$. The quality of the radical scavenging property of the sample extracts were determined by calculating $\mathrm{IC}_{50}$ value. $\mathrm{IC}_{50}$ (concentration providing $50 \%$ inhibition) values were calculated from percentage disappearance versus concentration plot.

\section{Ferric Reducing Antioxidant Power Assay (FRAP)}

The FRAP assay was performed according to Benzie and Strain with some modifications [32]. The following stock solutions were prepared for the analysis: $300 \mathrm{mM}$ acetate buffer $\mathrm{pH} 3.6,10 \mathrm{mM}$ TPTZ 
(2,4,6-tripyridyl-s-triazine) solution in $40 \mathrm{mM} \mathrm{HCl}$, and $20 \mathrm{M} \mathrm{FeCl}_{3} \cdot 6 \mathrm{H}_{2} \mathrm{O}$ solution. The fresh reagent was prepared from the stock solution by adding $25 \mathrm{~mL}$ acetate buffer, $2.5 \mathrm{~mL}$ TPTZ solution, and $2.5 \mathrm{~mL}$ $\mathrm{FeCl}_{3} \cdot 6 \mathrm{H}_{2} \mathrm{O}$ solution and warmed to $37^{\circ} \mathrm{C}$ before use. Sample extracts were allowed to react with FRAP solution in the ratio 1:20 for $30 \mathrm{~min}$ in the dark. The molar absorbance was measured for the product formed [ferrous tri-pyridyltriazine complex] at $593 \mathrm{~nm}$. Results were expressed as mg per $100 \mathrm{~g}$ extract weight $(\mathrm{mg} / 100 \mathrm{~g})$.

\section{HPLC Analysis of Phenolic Compounds}

Phenolic Compounds were separated and quantified in the extracted sample solution using HPLC-2707 Water system equipment with thermostatically controlled column oven and a diode array detector-2996. Samples and mobile phase were filtered with Advantech filter and analyzed by using reverse phase HPLC. Optimal separation was achieved using isocratic elution on a C18 column (250 $\mathrm{x}$ $4.6 \mathrm{~mm} \times 5 \mu \mathrm{m}$ ) at a flow rate of $1.1 \mathrm{~mL} / \mathrm{min}$ at $35^{\circ} \mathrm{C}$. The mobile phase used was methanol containing $0.2 \%$ phosphoric acid. All samples were injected three times using automatic sample injector. The spectral data of signals from PDA detector was measured at $360 \mathrm{~nm}$. The external standard method was used for identification and quantification of phenolic compounds and expressed as $\mathrm{mg} / 100 \mathrm{~g}$ of extract [33].

\section{Proximate Analysis}

The proximate analysis was determined by standard method [34]. Moisture, ash, protein, crude fiber and lipid content were determined by AOAC method. The samples were measured in triplicate for all samples.

\section{Determination of metals}

The metals were determined after drying the sample on a hot plate followed by ashing in the Muffle furnace (Metek Scientific Co. Ltd.). All glassware were thoroughly cleaned using freshly prepared $10 \%$ ( v/v) $\mathrm{HNO}_{3}$ for about $48 \mathrm{~h}$ and finally rinsed with double deionized water (DDW).

Samples were initially dried at $65^{\circ} \mathrm{C}$ for $48 \mathrm{~h}$ and brought to room temperature in a desiccator. About $1 \mathrm{~g}$ of dried and well homogenized sample was weighed accurately in a porcelain crucible and $2 \mathrm{~mL}$ of $6 \mathrm{M} \mathrm{HNO}_{3}$ was added. Mineralization was carried out in three stages: (i) the sample was initially heated in a muffle furnace at $100^{\circ} \mathrm{C}$ to evaporate excess reagents; (ii) further, sample was heated at $250^{\circ} \mathrm{C}$ for 30 minutes; (iii) followed by heating at $450^{\circ} \mathrm{C}$ for 4 hours. The sample was brought to room temperature in desiccator. The minerals and contaminants were brought into the solution by adding few drops of $\mathrm{HNO}_{3}$ and DDW and quantitatively transferred to $50 \mathrm{~mL}$ measuring flask and diluted with DDW. All samples were analyzed by ICP-MS.

\section{Statistical Analysis}

Each test assay was done three times from the same extract in order to determine their reproducibility. Results were expressed as mean values \pm standard deviation. Comparisons were performed by analysis of variance (ANOVA). The correlations among the data were calculated using Pearson's correlation coefficient $(r)$ and $p<0.05$ was considered as significantly different. Duncan's test was used to determine significant differences.

\section{RESULTS AND DISCUSSION Phytochemical Screening}

The sample extracts of pink and white guava fruits were tested for the presence of alkaloids, steroids, tannins, saponins and glycosides. The qualitative approach was used and expressed as (+) for the presence and (-) for the absence of phytochemicals.

The phytochemical screening of sample extracts of pink and white guava samples indicate the 
presence of secondary metabolites such as flavonoids, saponins, terpenoids, steroids, and coumarins (Table I). Alkaloids were detected in the peel extract but not in the seed extract. Due to the medicinal properties of these phytochemical compounds the screening was carried out [35-42].

Table I. Secondary metabolite detection

\begin{tabular}{lcc}
\hline Phytochemicals & Peel & Seeds \\
\hline Flavonoids & + & + \\
Tannin & + & + \\
Alkaloids & + & - \\
Phlobatannins & - & - \\
Saponins & + & + \\
Terpenoids & + & + \\
Steroids & + & + \\
Coumerins & + & + \\
\hline
\end{tabular}

\section{Total Phenolic Content}

The total phenolic content (TPC) of white and pink guava peel and seed extracts is tabulated in Table II. Phenolic compounds present in large amount in peel waste in fruits are considered to be an important constituent due to their antioxidant activity [43]. TPC expressed as gallic acid equivalent (GAE), varied from 57 to $432 \mathrm{mg} \mathrm{GAE} / 100 \mathrm{~g}$ in guava. In the present study TPC was found to be $339.9 \mathrm{mg}$ GAE/100 $\mathrm{g}$ in peel byproduct and in seed byproduct was $57.2 \mathrm{mg} \mathrm{GAE} / 100 \mathrm{~g}$ and similarly for pink flesh guava was $432.06 \mathrm{mg} \mathrm{GAE} / 100 \mathrm{~g}$ and $74.62 \mathrm{mg} \mathrm{GAE} / 100 \mathrm{~g}$ of peel and seed byproduct respectively. The highest ( $p \leq 0.05$ ) TPC were obtained for peel byproducts and the lowest for the seed byproducts. Total phenolic content were correlated with the antioxidant activity mentioned in Table II. These results are comparable with those obtained by Dasgupta et al. [44] and Dorman et al. [45] where they reported direct relationship between total phenolic content and antioxidant activity in many plant species.

Table II. Total phenolic content, total flavonoid content and antioxidant activity of peel and seed of white and pink guava fruit

\begin{tabular}{lcccc}
\hline Samples & TPC $(\mathbf{m g} / \mathbf{1 0 0} \mathbf{~ g})$ & TFC $(\mathbf{m g} / \mathbf{1 0 0} \mathbf{~ g})$ & IC $_{\mathbf{5 0}}(\mathbf{m g} / \mathbf{1 0 0} \mathbf{~ g})$ & FRAP $(\mathbf{m g} / \mathbf{1 0 0} \mathbf{~ g})$ \\
\hline $\begin{array}{l}\text { Guava Peel (white) } \\
\text { Guava Seed }\end{array}$ & $339.9 \pm 0.3^{\mathrm{a}}$ & $32.4 \pm 0.6^{\mathrm{b}}$ & $21.6 \pm 0.2^{\mathrm{b}}$ & $24.2 \pm 0.2^{\mathrm{b}}$ \\
(white) & $57.2 \pm 0.4^{\mathrm{c}}$ & $15.6 \pm 0.5^{\mathrm{a}}$ & $27.9 \pm 0.8^{\mathrm{a}}$ & $30.6 \pm 0.3^{\mathrm{a}}$ \\
Guava Peel (pink) & $432.1 \pm 0.7^{\mathrm{b}}$ & $33.0 \pm 0.5^{\mathrm{b}}$ & $20.5 \pm 0.2^{\mathrm{b}}$ & $19.6 \pm 0.3^{\mathrm{c}}$ \\
Guava Seed (pink) & $74.6 \pm 0.5^{\mathrm{d}}$ & $16.5 \pm 0.3^{\mathrm{c}}$ & $26.5 \pm 0.5^{\mathrm{a}}$ & $28.5 \pm 0.4^{\mathrm{a}}$ \\
\hline
\end{tabular}

The values of individual compounds were the mean \pm standard deviation $(n=3)$ and values followed by different letters in the same column are significantly $(p<0.05)$ different from each other.

\section{Total Flavonoids Content}

The flavonoid content of the extracts was investigated due to the power of these compounds to reduce oxidative damage to cells as demonstrated in several studies [44]. The flavonoids content of extracts was calculated as quercetin equivalent (QE). The total flavonoids content (TFC) in peel and seed extract was found to be $32.4 \mathrm{mg} \mathrm{QE} / 100 \mathrm{~g}$ and $15.6 \mathrm{mg}$ QE/100 $\mathrm{g}$ of white variety of guava and for pink guava was $33.0 \mathrm{mg} \mathrm{QE} / 100 \mathrm{~g}$ and $16.5 \mathrm{mg} \mathrm{QE} / 100 \mathrm{~g}$. TFC ranged from $15.6 \mathrm{mg} \mathrm{QE} / 100 \mathrm{~g}$ to 
$33.0 \mathrm{mg}$ QE/100 $\mathrm{g}$ in white guava and pink guava peel and seed extract. The higher $(p \leq 0.05)$ TFC yield were obtained for peel byproducts and the lowest for the seed byproducts. The TFC and antioxidant activity were also correlated as shown in Table II which indicates flavonoids might be responsible for its activity [47]. No significant $(p \leq 0.05)$ difference was found among guava white and guava pink peel extract in TFC.

\section{DPPH Activity}

The DPPH free radical scavenging by antioxidants is due to the hydroxyl group present in the sample. The large number of hydroxyl groups lead to greater radical scavenging activity. Phenolic compounds generally have significant scavenging effects for DPPH free radical [48-50]. The IC ${ }_{50}$ value for the sample extract defined as the concentration of extract causing $50 \%$ inhibition of absorbance was calculated. Lower the $\mathrm{IC}_{50}$ value, the higher the antioxidant power [51-52]. The results of $\mathrm{IC}_{50}$ of different samples of guava fruits are summarized in Table III. The $\mathrm{IC}_{50}$ value ranged from $20.5-27.9 \mathrm{mg} / 100$ $\mathrm{g}$ in white and pink guava peel and seed extract. Lower value in case of guava peel extract indicates the higher antioxidant power as compared to guava seed extract. The scavenging activity of sample extracts were in the order: guava peel (pink) > guava peel (white) > guava seed (pink) > guava seed (white). This is also in accordance with the reported literature where the values were $32-33 \mu \mathrm{g} / \mathrm{g}$ for the white variety and $15-16 \mu \mathrm{g} / \mathrm{g}$ of red variety of guava fruit flesh extract. Guava peel extract exhibited the higher $(p<0.05)$ antioxidant activity as compared to guava seed extract. The antioxidant activity of guava peel extract was similar with the whole guava fruit pomace and peel extract [53]. There is strong correlation with the TPC and TFC $\left(r^{2}=0.516\right)$.

\section{Ferric Reducing Antioxidant Power (FRAP) Activity}

The reducing antioxidant power of sample depends on its electron transfer ability towards the FRAP reagent. There was increase in absorbance which indicates its reductive ability. The reduction of ferrictri-pyridyl triazine to the ferrous complex develops an intense blue color, which was measured at $\lambda$ max of $593 \mathrm{~nm}$. The external standard calibration curve was used for the quantification. The result of the ferric ion reducing activities of the extracts is the presented in Table II. The result shows that the value is 24.2 and $30.6 \mathrm{mg} \mathrm{FeSO}_{4}$ equivalent $/ 100 \mathrm{~g}$ peel and seed of white guava and 19.6 and $28.5 \mathrm{mg} / 100 \mathrm{~g}$ for peel and seed of red guava. The value indicates the excellent reducing ability. It has been found that there is strong correlation between TPC and antioxidant activity as determined by FRAP and DPPH. The same correlations were also reported in fruit juices [54]. The difference in antioxidant activity as determined by DPPH and FRAP measurements is attributed to a relative difference in the ability of antioxidant compound to quench peroxyl radicals and to reduce the reagents (DPPH/iron).

\section{HPLC Analysis}

The extracted peels, seed and pomace samples were analyzed using HPLC instrument with diode array detector. The peaks in HPLC chromatogram were well separated indicating that the used HPLC conditions were optimum resulting in better efficiency of separation. Peaks were identified based on the retention time, and the concentrations of four phenolic components were determined by using external standard method. The phenolic compounds and flavonoids identified and quantified by HPLC are shown in Table III.

The result showed the phenolic compound varied in both white and pink variety of guava peel and seed. Among the phenolic compound chlorogenic acid present in fruit peels and seeds were in order: guava white > guava pink and it was higher in peel as compared to seed. 
Table III. Individual bioactive compounds in the white guava seed and peel, and pink guava seed and peel analyzed by HPLC $(\mathrm{mg} / 100 \mathrm{~g})$

\begin{tabular}{lcccc}
\hline Guava Sample & Peel-pink & Peel-white & Seed-pink & Seed-white \\
\hline Myricetin & $18.3 \pm 0.2^{\mathrm{c}}$ & $21.7 \pm 0.2^{\mathrm{b}}$ & $7.4 \pm 0.4^{\mathrm{d}}$ & $7.3 \pm 0.1^{\mathrm{d}}$ \\
Apigenin & $459.3 \pm 3.2^{\mathrm{b}}$ & $448.8 \pm 1.9^{\mathrm{d}}$ & $64.1 \pm 0.3^{\mathrm{a}}$ & $59.7 \pm 0.8^{\mathrm{c}}$ \\
Quercetin & $1.3 \pm 0.3^{\mathrm{a}}$ & $0.9 \pm 0.3^{\mathrm{b}}$ & $\mathrm{ND}$ & $\mathrm{ND}$ \\
Chlorogenic acid & $55.3 \pm 0.6^{\mathrm{d}}$ & $58.3 \pm 2.1^{\mathrm{a}}$ & $26.8 \pm 0.5^{\mathrm{b}}$ & $29.0 \pm 0.7^{\mathrm{c}}$ \\
\hline
\end{tabular}

The values of individual compounds were the mean \pm standard deviation $(n=3)$. Data with different letters in the same row is significantly difference at level $p<0.05$. ND is not detected.

In the present study it was observed that the flavonoids present were higher in pink variety as compared to white variety and were higher in peel as compared to seed. The amount of quercetin was found to be in the range of $0.9-1.3 \mathrm{mg} / 100 \mathrm{~g}$. An appreciable amount of quercetin was detected in the peel extracts of both white and pink guava and not detectable in the seed. Apegenin was found in appreciable amount in both peel and seed of guava white and pink varieties and it ranges from $448.8-459.3 \mathrm{mg} / 100 \mathrm{~g}$ in white and pink guava peel and ranges from $59.7-64.1 \mathrm{mg} / 100 \mathrm{~g}$ in white and pink guava seeds. Myricetin, with its three adjacent hydroxyl groups was one of the most active antioxidants. The poly-phenolic myricetin is a flavonol found in white and pink guava peel and seed. The amount ranges from $18.3-21.7 \mathrm{mg} / 100 \mathrm{~g}$ in white and pink guava peel and in seed it ranges from $7.3-7.4 \mathrm{mg} / 100 \mathrm{~g}$. Several studies had correlated that flavonoids are the main contributor for plant's antioxidant activity $[55,56]$. The strong oxidant activity by the guava peel extract may be attributed to the abundance of apigenin, myricetin, and chlorogenic acid.

\section{Proximate Analysis}

Proximate analysis of the seed and peel is done in order to know the nutrient content. According to Cabral et al. [57], the food value of guava fruit was $0.9 \%$ to $2 \%$ protein, $0.1 \%$ to $0.5 \%$ fat, $2.8 \%$ to $5.5 \%$ fibre along with minerals and vitamins in the whole guava fruit. Nutrient content of the peel and seed as shown in Table IV is significant and comparable.

Table IV. Proximate composition of guava seed and peel

\begin{tabular}{lcc}
\hline Parameters & Peel & Seed and pomace \\
\hline Moisture\% (Dry basis) & $3.49 \pm 0.12^{\mathrm{a}}$ & $2.77 \pm 0.24^{\mathrm{b}}$ \\
Total Protein & $0.91 \pm 0.07^{\mathrm{a}}$ & $0.70 \pm 0.11^{\mathrm{c}}$ \\
Crude fiber & $0.29 \pm 0.03^{\mathrm{c}}$ & $0.49 \pm 0.09^{\mathrm{b}}$ \\
Crude Fat & $0.06 \pm 0.01^{\mathrm{a}}$ & $0.08 \pm 0.02^{\mathrm{a}}$ \\
Ash & $0.024 \pm 0.006^{\mathrm{a}}$ & $0.011 \pm 0.005^{\mathrm{c}}$ \\
\hline
\end{tabular}

The values of individual compounds were the mean \pm standard deviation $(n=3)$ and values followed by same letters within the rows are not significantly $(p<0.05)$ different from each other.

The total protein content of peel and seed was $0.91 \%$ and $0.70 \%$; fat content was $0.06 \%$ and $0.70 \%$. The fat content is more in seed as it contains essential fatty acid; similarly, crude fiber was $0.2930 / \mathrm{g}$ in peel as compared to $0.4857 / \mathrm{g}$ in seed; ash indicates the mineral content which is $0.024 \%$ and $0.011 \%$ in dry peel and seed of guava respectively. 


\section{Trace metals and mineral analysis}

Certain metals such as $\mathrm{Cu}, \mathrm{Fe}, \mathrm{Mn}$ and $\mathrm{Zn}$ are the naturally occurring essential elements. Other metals such as $\mathrm{Pb}, \mathrm{Cr}, \mathrm{Ni}, \mathrm{As}$, and $\mathrm{Hg}$ are considered to be very toxic at very low concentrations. The amount of $\mathrm{Cu}, \mathrm{Fe}, \mathrm{Mn}, \mathrm{Zn}, \mathrm{Pb}, \mathrm{Cr}, \mathrm{Ni}, \mathrm{As}, \mathrm{V}$, and $\mathrm{Hg}$ in the peel and seed of guava white and pink variety were determined using ICP-MS method. Table $V$ shows the concentrations of all these metals. The toxic elements were present in less than $0.1 \mathrm{mg} / \mathrm{L}$ in all the samples which is below the toxic limit guide lines for fruits given by the regulations. The essential elements such as $\mathrm{Fe}, \mathrm{Mn}, \mathrm{Cu}$, and $\mathrm{Zn}$ were present in all these samples. The range of $\mathrm{Fe}, \mathrm{Cu}, \mathrm{Mn}$ and $\mathrm{Zn}$ concentrations were $0.50-1.10,0.10-0.30,0.13$ -0.42 , and $0.20-0.30 \mathrm{mg} \mathrm{L}^{-1}$ respectively.

Table V. Metal concentrations in both white guava seed and peel, and pink guava seed and peel (Psidium guajava) extract $\left(\mathrm{mg} \mathrm{L}^{-1}\right)$

\begin{tabular}{lcccccccccc}
\hline Sample & $\mathbf{V}$ & $\mathrm{Cr}$ & $\mathrm{Mn}$ & $\mathrm{Fe}$ & $\mathrm{Ni}$ & $\mathrm{Cu}$ & $\mathrm{Zn}$ & $\mathrm{As}$ & $\mathrm{Hg}$ & $\mathrm{Pb}$ \\
\hline WP & $<0.1$ & $<0.1$ & $0.41 \pm 0.04^{\mathrm{b}}$ & $0.60 \pm 0.03^{\mathrm{b}}$ & $<0.1$ & $0.10 \pm 0.01^{\mathrm{a}}$ & $0.20 \pm 0.06^{\mathrm{c}}$ & $<0.1$ & $<0.1$ & $<0.1$ \\
WS & $<0.1$ & $<0.1$ & $0.13 \pm 0.02^{\mathrm{a}}$ & $0.50 \pm 0.01^{\mathrm{a}}$ & $<0.1$ & $0.30 \pm 0.04^{\mathrm{c}}$ & $0.30 \pm 0.02^{\mathrm{c}}$ & $<0.1$ & $<0.1$ & $<0.1$ \\
RP & $<0.1$ & $<0.1$ & $0.42 \pm 0.06^{\mathrm{b}}$ & $1.10 \pm 0.04^{\mathrm{c}}$ & $<0.1$ & $0.10 \pm 0.01^{\mathrm{a}}$ & $0.30 \pm 0.03^{\mathrm{c}}$ & $<0.1$ & $<0.1$ & $<0.1$ \\
RS & $<0.1$ & $<0.1$ & $0.24 \pm 0.04^{\mathrm{c}}$ & $0.60 \pm 0.02^{\mathrm{b}}$ & $<0.1$ & $0.30 \pm 0.02^{\mathrm{c}}$ & $0.30 \pm 0.02^{\mathrm{c}}$ & $<0.1$ & $<0.1$ & $<0.1$ \\
\hline
\end{tabular}

$\mathrm{WP}=$ white guava peel; $\mathrm{WS}=$ white guava seed; $\mathrm{RP}=$ pink guava peel; $\mathrm{RS}$ = pink guava seed. The values of individual compounds were the mean \pm standard deviation $(n=3)$ and values in the same column followed by different letters are significantly $(p<0.05)$ different from each other.

\section{CONCLUSION}

The waste byproduct of fruits and vegetables is already been a major issue in the food sector in the developing countries. To compensate the losses occurring in the fruit processing industry, it is required that the proper waste management is followed and directing the energy in the right direction. The observed results indicate that its bioactive compound content and antioxidant activity as determined by performing the various assays like free radical scavenging activity through DDPH assay, and FRAP assay are found to be excellent. The FRAP activity shows that it is 24.2 and 30.6 mg FeSO equivalent $/ 100 \mathrm{~g}$ peel and seed of white guava and similarly 19.6 and $28.5 \mathrm{mg} / 100 \mathrm{~g}$ for peel and seed of red guava. The $\mathrm{IC}_{50}$ value ranged from $20.5-27.9 \mathrm{mg} / 100 \mathrm{~g}$ in white and pink guava peel and seed extract. The results of TPC show that there is $339.9 \mathrm{mg} \mathrm{GAE} / 100 \mathrm{~g}$ of peel and that of seed is 57.2 $\mathrm{mg} / 100 \mathrm{~g}$ and similarly for pink flesh guava is $432.1 \mathrm{mg} \mathrm{GAE} / 100 \mathrm{~g}$ and $74.6 \mathrm{mg} \mathrm{GAE} / 100 \mathrm{~g}$ of peel and seed respectively. Result of total flavonoid content (TFC) in peel and seed extract is $32.4 \mathrm{mg} / 100 \mathrm{~g}$ and $15.6 \mathrm{mg} \mathrm{QE} / 100 \mathrm{~g}$ of white variety of guava and that of pink guava is $33.0 \mathrm{mg} \mathrm{QE} / 100 \mathrm{~g}$ of guava. The above results show that phenolic content of the seed, peel and pomace of guava fruit are present in significant amount indicative of its antioxidant activity.

The nutrient content observed in the peel and seed of the white and pink flesh guava indicates its excellent food value. The total protein content of peel and seed is $0.91 \%$ and $0.70 \%$; fat content is $0.06 \%$ and $0.70 \%$ - the fat content is more in seed as from the literature review it contains essential fatty acid in it; similarly, crude fiber is $0.2930 / \mathrm{g}$ in peel as compared to $0.4857 / \mathrm{g}$ in seed; ash indicates the mineral content which is $0.024 \%$ and $0.011 \%$ in dry peel and seed of guava respectively. It indicates that along with the good nutrient content it has excellent bioactive compound with significant antioxidant activity. The bioactive compounds present in by-product of the fruit processing can be utilized for various other purposes like value added processing, as functional food, food additives, therapeutic applications, for fortifications and many more. 
Manuscript received: 05/21/18; revised manuscript received: $07 / 29 / 18$; revised manuscript for the $2^{\text {nd }}$ time received: 09/07/18; revised manuscript for the $3^{\text {rd }}$ time received: 09/25/18; revised manuscript for the $4^{\text {th }}$ time received: $10 / 25 / 18$; manuscript accepted: $12 / 19 / 18$; published online: 02/07/19.

\section{REFERENCES}

1. Kamle M.; Baek K. H. 3 Biotech, 2017, 7 (3), p 203. doi: 10.1007/s13205-017-0844-0

2. Lim Y. Y.; Lim, T. T.; Tee, J. J. Sunway Academic Journal, 2006, 3, pp 9-20.

3. Silva, L. M. R; Figueiredo, E. A. T.; Ricardo, N. M. P. S.; Vieira; I. G. P.; Figueiredo, R. W.; Brasil, I. M.; Gomes, C. L. Food Chem., 2014, 143, pp 398-404. doi: 10.1016/j.foodchem.2013.08.001

4. Ishartani D.; Rahman F. L. F.; Hartanto R.; Utami R.; Khasanah L. U. IOP Conf. Series: Earth and Environmental Science, 2018, 102, 012075. doi: 10.1088/1755-1315/102/1/012075

5. Souza, H. A.; Parent, S. E.; Rozane, D. E.; Amorim, D. A.; Modesto, V. C.; Natale, W.; Parent L. E. Front. Plant Sci., 2016, 7:1252. doi: 10.3389/fpls.2016.01252

6. Bueno, J. M.; Saez-Plaza, P.; Ramos-Escudero, F.; Jimenez, A. M.; Fett, R.; Asuero, A. G. Crit Rev. Anal. Chem., 2012, 42, pp 126-151. doi: 10.1080/10408347.2011.632314

7. Snyder, S. M.; Reber, J. D.; Freeman, B. L.; Orgrad, K.; Eggett, D. L.; Parker T. L. Nutr. Res., 2011, 31, pp 519-526. doi: 10.1016/j.nutres.2011.06.006

8. Tanaka, T.; Shnimizu, M.; Moriwaki, H. Molecules, 2012, 17, pp 3202-3242. doi: 10.3390/molecules17033202

9. Soong, Y. Y.; Barlow, P. J. Food Chem., 2004, 88, pp 411-417.

10. Zeisel, S. H. Science, 1999, 285, pp 1853-1855. doi: 10.1126/science.285.5435.1853

11. Kaur, K. Nutraceuticals. Elsevier, London, 2016, pp 41-78.

12. Siro, I.; Kapolna, E.; Kapolna, B.; Lugasi, A. Appetite, 2008, 51, pp 456-467. doi: 10.1016/j.appet.2008.05.060

13. Kosseva, M.; Webb, C. (Eds). Food Industry Wastes. Elsevier, London, 2013.

14. Jayathunge, K. G. L. R.; Stratakos, A. C.; Cregenzán-Albertia O.; Grant, I. R.; Lyng, J.; Koidis, A. Food Chem., 2017, 221, pp 698-705. doi: 10.1016/j.foodchem.2016.11.117

15. Kammerer, D.; Claus, A.; Carle, R.; Schieber, A. J. Agric. Food Chem., 2004, 52, pp 4360-4367. doi: 10.1021/jf049613b

16. Astuti, W. F. P.; Nainggolan, R. J.; Nurminah, M. J. Rekayasa Pangan dan Pertanian, 2016, 4 (1), pp 65-71.

17. Gowe, C. Food Science and Quality Management, 2015, 45, pp 47-61.

18. Zulkifli, K. S.; Abdullah, N.; Abdullah, A.; Aziman, N.; Kamarudin W. S. S. W. International Conference on Environment, Chemistry and Biology IPCBEE, 2012, 49, pp 66-70. doi: 10.7763/IPCBEE.2012.V49.14

19. Kumar, K.; Yadav, A. N.; Kumar, V.; Vyas, P.; Dhaliwal, H. S. Bioresources \& Bioprocessing, 2017, 4(18). doi: 10.1186/s40643-017-0148-6

20. Shahidi, F. J. Food Drug Anal., 2012, 20(1), pp 226-230.

21. Scheiber, A.; Hilt, P.; Streker, P.; Endress, H. U.; Rentschler, C.; Carle, R. Innovative Food Sci. Emerging Technol. 2003, 4(1), pp 99-107. doi: 10.1016/S1466-8564(02)00087-5

22. Sudha, M. L.; Baskaran, V.; Leelavathi, K. Food Chem., 2007, 104, pp 686-692.

23. Williams, A. B.; Ayejuyo, O. O.; Ogunyale, A. F. Environ. Monit. Assess., 2009, 156, pp 303-306. doi: 10.1007/s10661-008-0485-1

24. Association of Official Analytical Chemists (AOAC). Official Methods of Analysis, $15^{\text {th }}$ ed. Washington, D.C., 1996.

25. Association of Official Analytical Chemists (AOAC). Official Methods of Analysis, Method 935.14, $18^{\text {th }}$ ed. Washington D.C., 2005. 
26. Akinpelu, A. D.; Awotorebo, T. O.; Agunbiade, O. M.; Aiyegoro, A. O.; Okoh, I. A. J. Med. Plants Res., 2011, 5(11), pp 2398-2404.

27. Vasco, C.; Ruales, J.; Kamal-Eldin, A. Food Chem., 2008, 111, pp 816-823.

28. Li, L.; Chen, C. Y. O.; Chun, H. K.; Cho, S. M.; Park, K. M.; Lee-Kim, Y. C.; Blumberg, J. B.; Russell, R. M.; Yeum, K. J. J. Nutr. Biochem., 2009, 20(3) 219-226. doi: 10.1016/j. jnutbio.2008.02.006

29. Harborne, J. B. Phytochemical Methods: A guide to modern techniques of plant analysis, $3^{\text {rd }}$ edition. Chapman \& Hall, London, 1998, pp 49-188.

30. Singleton V. L.; Rossi, J. A. Am. J. Enol. Vitic. 1965, 16, pp 144-158.

31. Brand-William, W.; Cuvelier, M. E.; Berset, C. Lebenson Wiss Technol. 1995, 28(1), pp 25-30. doi: 10.1016/S0023-6438(95)80008-5

32. Benzie, I. F. F.; Strain, J. J. Anal. Biochem., 1996, 239(1), pp 70-76. doi: 10.1006/abio.1996.0292

33. Boligon, A. A.; De Brum, T. F.; Frolhich, J. K.; Froeder, A. L. F.; Athaye, M. L. Res. J. Phytochem. 2012, 6(3), pp 84-91. doi: 10.3923/rjphyto.2012.84.91

34. Official Methods of Analysis of AOAC International, $18^{\text {th }}$ ed. Gaithersburg, MD, 2008. Available from: https://www.researchgate.net/publication/292783651_AOAC_2005

35. Souto, A. L.; Tavares, J. F.; Da Silva, M. S.; Diniz, M. F. F. M.; De Athayde-Filho, P. F.; Barbosa Filho, J. M. Molecules, 2011, 16(10), pp 8515-8534. doi: 10.3390/molecules16108515

36. Dua, V. K.; Gaurav, V.; Bikram, S.; Aswathy, R.; Upma, B.; Dau, D. A.; Gupta, N. C.; Sandeep, K.; Ayushi, R. Malaria J. 2013, 12. doi: 10.1186/1475-2875-12-194

37. Benbott, A.; Yahyia, A.; Belaïdi, A. J. Nat. Prod. Plant Resour., 2012, 2, pp 568-573.

38. Ameyaw, Y.; Duker-Eshun, G. Int. J. Chem. Sci., 2009, 7(1), pp 48-58.

39. Thite, S. V.; Chavan, Y. R.; Aparadh, V. T.; Kore, B. A. Int. J. Pharm. Chem. Biol. Sci., 2013, 3, pp 87-90.

40. Bagrov, A. Y.; Shapiro, J. I.; Fedorova, O. V. Pharmacol. Rev. 2009, 61(1), pp 9-38. doi: 10.1124/pr.108.000711

41. Akiyama, H.; Fujii, K.; Yamasaki, O.; Oono, T.; Iwatsuki, K. J. Antimicrob. Chemother., 2001, 48(4), pp 487-491. doi: 10.1093/jac/48.4.487

42. Kumari, M.; Jain, S. Res. J. Recent Sci., 2012, 1, pp 70-73.

43. Luximon-Ramma, A.; Bahorun, T.; Crozier, A. J. Sci. Food and Agric. 2003, 83, pp 496-502. doi: 10.1002/jsfa.1365

44. Dasgupta, N.; De, B. Food Chem., 2004, 88(2), pp 219-224. doi:10.1016/j.foodchem.2004.01.036

45. Dorman, H. J. D.; Hiltunen, R. Food Chem., 2004, 88(2) pp 193-199. doi: 10.1016/j.foodchem.2003.12.039

46. Prior, R. L.; Hoang, H.; Gu, L.; Wu, X.; Bacchiocca, M.; Howard, L.; Hampsch-Woodill, M.; Huang, D.; Ou, B.; Jacob, R. J. Agric. Food Chem., 2003, 51(11), pp 3273-3279. doi: 10.1021/jf0262256

47. Kessler, M.; Ubeaud, G.; Jung, L. J. Pharm. Pharmacol., 2003, 55, pp 131 -142. doi: 10.1211/002235702559

48. Bandonienè, D.; Murkovic, M.; Pfannhauser, W.; Venskutonis, P.; Gruzdienè, D. Eur. Food Res. Technol., 2002, 214(2), pp 43-147. doi: 10.1007/s00217-001-0430-9

49. Norshazila, S.; Syed Zahir, I.; Mustapha Suleiman, K.; Aisyah, M. R.; Kamarul Rahim, K. Malaysian Journal of Nutrition, 2010, 16(1), pp 149-159.

50. Mensor, L. L.; Menezes, F. S.; Leitão, G. G.; Reis, A. S.; dos Santos, T. C.; Coube, C. S.; Leitão, S. G. Phytother. Res., 2001, 15, pp 127-130. doi: 10.1002/ptr.687

51. Awika, J. M.; Rooney, L. W.; Wu, X.; Prior, R .L.; Cisneros-Zevallos, L. J. Agric. Food Chem., 2003, 51(23), pp 6657-6662. doi: 10.1021/jf034790i

52. Arnao, M. B.; Cano, A.; Acosta, M. Food Chem, 2001, 73(2), pp 239-244. doi: 10.1016/S0308-8146(00)00324-1

53. Thaipong, K.; Boonprakob, U.; Crosby, K.; Cisneros-Zevallos, L.; Byrne, D. H. J. Food Compos. 
Anal. 2006, 19(6-7), pp 669-675. doi:10.1016/j.jfca.2006.01.003

54. Gardner, P. T.; White, T. A. C.; McPhail, D. B.; Duthie, G. G. Food Chem., 2000, 68(4), pp 471474. doi: 10.1016/S0308-8146(99)00225-3

55. Merken, H. M.; Beecher, G. R. J. Agric. Food Chem., 2000, 48(3), pp 577-599. doi: 10.1021/JF9908720

56. Chun, O. K.; Chung, S. J.; Song, W. O. J. Nutr., 2007, 137(5), pp 1244-1252. doi: $10.1093 / J N / 137.5 .1244$

57. Cabral, R. A. F.; Telis-Romero, J.; Telis, V. R. N.; Gabas, A. L.; Finzer, J. R. D. J. Food Eng., 2007, 80(4), pp 1096-1106. doi: 10.1016/j.jfoodeng.2006.09.002 